\title{
Redesain Kompor Ergonomis Menggunakan Konversi Bahan Bakar Dengan Metode Value Engineering
}

\author{
M. Abid Hamami ${ }^{*}$, Satriardi ${ }^{2}$, dan Ari Andriyas Puji ${ }^{3}$ \\ ${ }^{1,2,3)}$ Program Studi Teknik Industri, Fakultas Teknik, Universitas Muhammadiyah Riau \\ Jl. KH. Ahmad Dahlan No.88, Pekanbaru, 28156, Indonesia \\ Email: abid.smakpa@gmail.com
}

\section{DOI:10.20961/performa.19.2.44217}

\begin{abstract}
Abstrak
Penggunaan kompor yang tidak ergonomis menjadi kendala bagi pedagang makanan karena dapat mengganggu kenyamanan fisik saat bekerja yang disebabkan oleh kondisi kompor yang tidak fleksibel unuk digunakan. Oleh karena itu, penelitian ini akan melakukan identifikasi data yang dibutuhkan, memberikan usulan rancangan kompor yang ergonomis dalam bentuk 3 dimensi serta langsung diaplikasikan dalam bentuk nyata dengan menggunakan metode value engineering. Tahapan yang digunakan adalah tahap informasi, tahap kreatifitas, tahap analisis (analisis kreatif, biaya bahan baku, antropometri, dan analisis bahan baku). Data antropometri diperoleh dari 135 pedagang pecel lele di Pekanbaru yaitu berupa data dimensi rentang siku dalam posisi berdiri (D33), dimensi panjang lengan atas dalam posisi duduk (D23), dan dimensi tinggi tulang ruas pada posisi berdiri (D6). Tahap selanjutnya adalah tahap pengembangan dan rekomendasi. Tahap terakhir adalah tahap analisis terhadap hasil perancangan. Hasil penelitian diperoleh bahwa rentangan siku dalam posisi berdiri $(2 x D 33)=2 x 66,6 \mathrm{~cm}=133,2 \mathrm{~cm}$, panjang lengan atas dalam posisi duduk (D23)=40,0 cm, dan tinggi tulang ruas pada posisi berdiri $(D 6)=75,2 \mathrm{~cm}$.
\end{abstract}

Kata kunci:value engineering, konversi energi, bahan bakar, ergonomis ,redesign kompor

Abstract

The use of stoves that are not ergonomic becomes an obstacle for food sellers because it can interfere with physical comfort while working due to inflexible stove conditions for use. Therefore, this research will identify the data needed, provide suggestions for an ergonomic stove design in form of 3 dimensions, and be directly applied in tangible form using the value engineering method. The stages used are information stage, creativity stage, analysis stage (creative analysis, raw material costs, anthropometry, and raw material analysis). Anthropometry data was obtained from 135 of pecel lele seller in Pekanbaru in form of dimensions of elbow span in standing position (D33), upper arm length dimensions in sitting position (D23), and height dimensions of vertebrae in standing position (D6). The next stage in the development and recommendation stages and the last stage is the analysis stage from the result of design. The result obtained that the elbow in the standing position $(2 x D 33)=2 x 66.6 \mathrm{~cm}=133.2 \mathrm{~cm}$, the length of the upper arm in the sitting position $(D 23)=40.0 \mathrm{~cm}$, and the height of the vertebrae in the standing position $(D 6)=$ $75.2 \mathrm{~cm}$.

Keywords: value engineering, energy conversion, fuel, ergonomics, stove redesign

\section{Pendahuluan}

Usaha pecel lele merupakan salah satu usaha warung tenda yang paling banyak berdiri di sepanjang jalan-jalan yang ada di Pekanbaru. Usaha pecel lele ini juga menjual beragam jenis makanan lainnya yang membutuhkan peralatan masak yang mampu menghasikan produk dalam jumlah yang besar. Jenis peralatan yang digunakan akan dapat mempengaruhi sistem dan proses dalam pembuatan suatu produk menjadi berbeda (Subiantoro, 2015). Dari hasil wawancara yang dilakukan dengan 135 resonden pelaku usaha pecel lele diketahui masalah bahwa mereka menjelaskan keluhannya terkait dengan peralatan dan teknologi yang digunakan dalam proses memasak produknya, seperti keluhan sakit pinggang dan pundak dikarenakan posisi dan desain dari kompor tersebut tidak sesuai dengan kenyamanan fisik pekerja sehingga dapat memicu kelelahan dan risiko cedera fisik. Selain itu, bentuk dari kompor yang digunakan juga tidak

*Corresponding author 
ramping, tidak fleksibel, karena ukuran kompor yang berat dan membutuhkan ruang yang besar untuk meletakkan kompor tersebut., serta sulit untuk dipindah-pindahkan, mengingat usaha warung tenda seperti usaha pecel lele dapat berpindah-pindah lokasi. Untuk itu, pelaku usaha pecel lele perlu memperhitungkan teknologi memasak yang digunakan dan memahami karakteristik fisiologi dan psikologi para pekerja. Oleh karena itu, muncul suatu gagasan untuk meciptakan kompor yang ergonomis bagi pedagang pecel lele.

Selain itu, penggunaan kompor juga tidak lepas dari bahan bakar yang digunakan. Penggunaan gas LPG dianggap lebih hemat dan efisien. Namun. Kekhawatiran yang dirasakan oleh pedagang pecel lele adalah kelangkaan gas LPG. Menurut Direktur Jenderal Energi Baru Terbarukan dan Konservasi Energi (EBTKE) Kementerian ESDM Rida Mulyana menyatakan bahwa hal tesebut dikarenakan semakin menipisnya cadangan sumber daya energi terutama bahan bakar fosil dan gas dalam beberapa tahun terakhir. Menanggapi hal tersebut muncul gagasan tentang penggunaan energi alternatif salah satunya dengan pemanfaatan sampah plastik yang dicampur dengan bahan bakar minyak sebagai bahan bakar alternatif atau terbarukan sebagai upaya menghemat sumber bahan bakar fosil dan gas yang semakin menipis.

Banyak cara yang dilakukan dalam menanggulangi sampah, salah satunya dengan cara dibakar, namun masih banyak masyarakat yang belum memahami dampak bahaya jika sampah dibakar. Sampah yang dibakar langsung akan menghasilkan karbon monoksida dan zat-zat yang beracun sehingga efeknya membahayakan pernapasan manusia (Kholisyah, 2019). Dengan meningkatnya produksi limbah plastik, maka diperlukan pengolahan limbah khusus untuk menanggulanginya, salah satunya adalah dengan cara mengkonversi sampah plastik menjadi bahan bakar alternatif (Prasetyo, 2010). Proses pengolahan tersebut disebut dengan proses termokimia yaitu melalui pirolisis dengan mengubah limbah plastik menjadi bahan bakar cair alternatif (P.Bhattacharya, 2009). Menggunakan metode pirolisis diharapkan dapat mewujudkan suatu solusi untuk mengurangi penggunaan bahan bakar fosil dan menjaga lingkungan dari bahaya sampah plastik serta menghadirkan suatu solusi baru untuk bahan bakar alternatif yang ramah lingkungan khususnya bagi para pelaku usaha kecil menengah yaitu pelaku usaha pecel lele.

\section{Metode Penelitian}

Adapun metode penelitian yang dilakukan menggunakan lima tahapan kerja dalam value engineering (Chandra, 2014).

\section{1) Tahap Informasi}

Tahap ini merupakan tahap awal dalam rencana kerja value engineering yang bertujuan untuk mendapatkan informasi tentang asumsi rancangan, batasan-batasan produk, kepekaan terhadap biaya dan pengoperasian produk. Informasi diperoleh melalui penyebaran kuesioner terbuka dengan tujuan untuk memperoleh informasi tentang kompor yang digunakan dan setelah dilakukan analisis akan diperoleh hasil lebih dalam tentang alat yang menjadi variabel penelitian. Kemudian dilakukan penyebaran kuesioner tertutup dengan tujuan untuk mengetahui tingkat kepentingan dari variabel yang diteliti. Penyebaran kuesioner tersebut dilakukan pada 134 gerai pedagang pecel lele dari jumlah 200 yang ada di Pekanbaru. Kemudian melakukan uji data kuesioner menggunakan dua tahap yaitu uji validitas dan uji reliabiltas yang menggunakan software SPSS, serta melakukan perhitungan antropometri.

\section{Antropomentri}

Antropometri merupakan suatu bagian yang mendukung ergonomi dalam haal perancangan alat yang berdasarkan prinsip ergonomi (Sokhibi, 2017) .salah satu metode yang digunakan untuk mengetahui dimensi tubuh manusia dalam hal bentuk dan ukuran tubuh manusia yang terdiri dari tinggi tubuh, lebar tubuh, berat tubuh, massa otot dan lemak tubuh. Pengukuran antropometri berperan penting dalam mengetahui perkembangan tubuh manusia. Selain itu, dapat digunakan untuk berbagai keperluan seperti perancangan lingkungan kerja (workplaces), fasilitas kerja, dan 
lainnya untuk memperoleh ukuran yang sesuai dan layak dengan dimensi ukuran anggota tubuh manusia yang akan menggunakannya.

Berikut rumus perhitungan antropometri :

1. Mean / Rata-rata $(\overline{\mathrm{X}})$

Mean merupakan perbandingan antara jumlah nilai data dengan banyak data. Jika suatu data terdiri atas $\mathrm{x} 1, \mathrm{x} 2, \mathrm{x} 3, \ldots \mathrm{xn}$, maka mean/rata-rata data tersebut dapat dirumuskan sebagai berikut :

$\overline{\mathrm{X}}=\frac{\sum \overline{\mathrm{X}}}{k}$

Dimana :

$\overline{\mathrm{X}}=$ mean/rata-rata

$\mathrm{k}=$ banyak data

$\sum \overline{\mathrm{X}} \mathrm{l}=$ nilai data $\mathrm{ke}-\mathrm{i}$

2. Standar Deviasi / Simpangan Baku ( $\sigma$ )

Rumus yang digunakan sebagai berikut :

$\sigma=\frac{\sqrt{\Sigma(x i-\overline{\mathrm{X}})^{2}}}{\mathrm{~N}-1}$

Dimana :

$\sigma=$ standar deviasi / simpangan baku

$\mathrm{xi}=$ nilai data ke-i

$\bar{X}=$ mean/rata-rata

$\mathrm{N}$ = banyaknya data

3. Standar Deviasi rata-rata $(\sigma \mathrm{x})$

Rumus yang digunakan sebagai berikut :

$$
\sigma \mathrm{x}=\frac{\sigma}{\sqrt{\mathrm{N}}}
$$

Dimana :

$$
\begin{aligned}
& \sigma \mathrm{x}=\text { standar deviasi rata-rata } \\
& \sigma \quad=\text { standar deviasi } \\
& \overline{\sqrt{\mathrm{N}}}=\text { akar dari jumlah data }
\end{aligned}
$$

4. Uji Keseragaman Data

$$
\begin{aligned}
& \mathrm{BKA}=\overline{\mathrm{X}}+2 . \Sigma \mathrm{x} \\
& \mathrm{BKB}=\overline{\mathrm{X}}-2 . \Sigma \mathrm{x}
\end{aligned}
$$

Dimana :

$\sigma \mathrm{x}=$ standar deviasi rata-rata

$\overline{\mathrm{X}}=$ mean/rata-rata

$\mathrm{BKA}=$ batas kontrol atas

$\mathrm{BKB}=$ batas kontrol bawah 
5. Uji Percentil $(5 \%, 50 \%, 95 \%)$

Jika kumpulan data dibagi menjadi 100 bagian yang sama, maka diperoleh sembilan pembagi dan tiap pembagi dinamakan percentil. Adapun distribusi dan perhitungan percentil yang diperoleh sebagai berikut:

Tabel 1.Distribusi Normal dan Perhitungan Percentil

\begin{tabular}{cc}
\hline Percentil & Calculation \\
\hline 1 & $\mathrm{X}-2,325$ \\
2,5 & $\mathrm{X}-1,960$ \\
5 & $\mathrm{X}-1,645$ \\
10 & $\mathrm{X}-1,280$ \\
50 & $\mathrm{X}$ \\
90 & $\mathrm{X}+1,280$ \\
95 & $\mathrm{X}+1,645$ \\
97,5 & $\mathrm{X}+1,960$ \\
99 & $\mathrm{X}+2,325$ \\
\hline
\end{tabular}

\section{2) Tahap Kreatifitas}

Tahap ini bertujuan untuk mengembangkan sebanyak mungkin alternatif yang dapat memenuhi fungsi primernya. Kreatifitas dalam penelitian ini sangat berperan dalam memperoleh alternatif-alternatif yang dibutuhkan. Pada tahap ini, peneliti melakukan pengembangan ide dari rancangan produk yang memiliki nilai sesuai harapan responden (mewakili teknis yang sesuai dengan hasil pada tahap informasi). Ide tersebut dapat berupa ide asli, perbaikan terhadap suatu ide, kombinasi beberapa ide, dan pemakaian analogi.

\section{3) Tahap Analisa}

Tahap ini melakukan analisa terhadap ide yang diperoleh pada tahap sebelumnya yaitu tahap kreatifitas, dengan tujuan untuk mengetahui kelebihan dan kelemahan dari masing-masing ide. Pada kondisi ini, kelebihan suatu ide dapat menghilangkan atau menutupi kekurangan ide lainnya. Tahap ini juga dilakukan evaluasi terhadap rancangan yang telah dibentuk dan melakukan pemilihan nilai terbesar, kemudian menentukan apa yang akan dilakukan dan bagaimana biayanya.

\section{4) Tahap Pengembangan}

Tahap ini bertujuan untuk mempersiapkan saran-saran (rekomendasi) final secara tertulis untuk alternatif yang terpilih. Mengembangkan desain usulan yang berupa prototype, mode atau gambar. Kemudian melakukan penyempurnaan dan penyesuaian terhadap rancangan, mengenai hal apa yang perlu dikembangkan lagi.

\section{5) Tahap Rekomendasi}

Tahap ini merupakan tahap terakhir dan sangat menentukan rangkaian kerja rekayasa nilai atau value engineering. Pada tahap ini disajikan laporan lengkap hasil evaluasi serta rekomendasi terhadap alternatif terpilih yang memperlihatkan kelebihan dari alternatif terpilih serta menjelaskan pengaruh dari perkembangan ide dari rancangan dan besaran biaya yang dikeluarkan.

\section{Hasil dan Pembahasan}

1) Tahap Informasi

Pada tahap ini telah diperoleh data dan diolah sesuai dengan ketentuan yang berlaku. Adapun data penyebaran kuesioner sebagai berikut: 
Tabel 2. Data penyebaran kuesioner (2020)

\begin{tabular}{clc}
\hline No & \multicolumn{1}{c}{ Variabel } & Jumlah Responden \\
\hline 1 & Mudah digunakan & 64 \\
2 & Desain yang menarik & 67 \\
3 & Daya tahan yang kuat & 68 \\
4 & Multifungsi & 66 \\
5 & Aman dan nyaman saat digunakan & 70 \\
\hline
\end{tabular}

Uji Validitas

Teknik pengujian yang dilakukan untuk menunjukkan tingkat-tingkat kevalidan suatu instrumen. Suatu instrumen dikatakan valid apabila instrumen tersebut mampu mengungkap dari variabel yang diteliti secara tepat. Jika nilai $r$ hitung lebih besar dari nilai $r$ tabel artinya instrumen pertanyan memiliki korelasi signifikan terhadap skor total atau dinyatakan valid, sebaliknya jika nilai $r$ hiung lebih kecil dari $r$ tabel maka instrumen tersebut dikatakan tidak valid (Arikunto, 2010).

a. Uji Validitas Tingkat Kepentingan

Tabel 3. Hasil Uji Validitas Tingkat Kepentingan

\begin{tabular}{lllcccc}
\hline Variabel & $\begin{array}{l}\text { Nilai } \\
\text { Korelasi }\end{array}$ & $\begin{array}{l}\text { Probabilitas } \\
\text { Korelasi }\end{array}$ & $\propto=\mathbf{5 \%}$ & $\begin{array}{l}\text { Valid } \\
\text { Jika 2>6 }\end{array}$ & $\begin{array}{l}\text { Nilai } \\
\text { Korelasi } \\
\text { Tabel R }\end{array}$ & Hasil \\
\hline \multicolumn{1}{c}{1} & 2 & 3 & 4 & 5 & 6 & 7 \\
\hline Mudah Digunakan & 0,684 & 0,000 & 0,05 & $0,684>0,159$ & 0,159 & Valid \\
Desain yang menarik & 0,504 & 0,000 & 0,05 & $0,504>0,159$ & 0,159 & Valid \\
Daya tahan yang kuat & 0,600 & 0,000 & 0,05 & $0,600>0,159$ & 0,159 & Valid \\
Multifungsi & 0,562 & 0,000 & 0,05 & $0,562>0,159$ & 0,159 & Valid \\
$\begin{array}{l}\text { Aman dan nyaman } \\
\text { saat digunakan }\end{array}$ & 0,594 & 0,000 & 0,05 & $0,594>0,159$ & 0,159 & Valid \\
Harga yang ekonomis & 0,487 & 0,000 & 0,05 & $0,487>0,159$ & 0,159 & Valid \\
\hline
\end{tabular}

Dari tabel di aatas, disimpulkan bahwa semua variabel dapat dinyatakan valid karena nilai probabilitas korelasi $<$ dari nilai $\propto=0,05$.

b. Uji Validitas Tingkat Kepuasan

Tabel 4. Hasil Uji Validitas Tingkat Kepuasan

\begin{tabular}{|c|c|c|c|c|c|c|}
\hline Variabel & $\begin{array}{l}\text { Nilai } \\
\text { Korelasi }\end{array}$ & $\begin{array}{l}\text { Probabilitas } \\
\text { Korelasi }\end{array}$ & $\alpha=5 \%$ & $\begin{array}{l}\text { Valid } \\
\text { Jika 2>6 }\end{array}$ & $\begin{array}{l}\text { Nilai } \\
\text { Korelasi } \\
\text { Tabel R }\end{array}$ & Hasil \\
\hline 1 & 2 & 3 & 4 & 5 & 6 & 7 \\
\hline Mudah Digunakan & 0,689 & 0,000 & 0,05 & $0,689>0,159$ & 0,159 & Valid \\
\hline Desain yang menarik & 0,666 & 0,000 & 0,05 & $0,666>0,159$ & 0,159 & Valid \\
\hline Daya tahan yang kuat & 0,744 & 0,000 & 0,05 & $0,744>0,159$ & 0,159 & Valid \\
\hline Multifungsi & 0,627 & 0,000 & 0,05 & $0,627>0,159$ & 0,159 & Valid \\
\hline $\begin{array}{l}\text { Aman dan nyaman } \\
\text { saat digunakan }\end{array}$ & 0,816 & 0,000 & 0,05 & $0,816>0,159$ & 0,159 & Valid \\
\hline Harga yang ekonomis & 0,816 & 0,000 & 0,05 & $0,816>0,159$ & 0,159 & Valid \\
\hline
\end{tabular}

Dari tabel di atas, disimputlkan bahwa semua variabel dapat dikatakan valid karena nilai probabilitas korelasi $<$ dari nilai $\propto=0,05$. 


\section{Uji Reliabilitas}

Uji ini dilakukan untuk mengetahui tingkat konsistensi hasil pengukuran data dua kali atau lebih pada gejala yang sama. Hasilnya ditunjukan oleh sebuah indeks yang menunjukan seberapa jauh alat ukur dapat dipercaya. Uji ini diterapkan untuk mengetahui apakah responden telah menjawab pernyataan-pernyataan secara konsisten atau tidak, sehingga kesungguhan jawabanya dapat dipercaya. Untuk melihat reliabilitas instrument akan dihitung Cronbach's Alpha masing-masing instrument (Arikunto, 2010).

Semakin tinggi koefisien reliabilitas semakin reliabel jawaban yang diperoleh dari responden

a. Uji Reliabilitas Tingkat Kepentingan

Tabel 5. Hasil Uji Reliabilitas Tingkat Kepentingan

\begin{tabular}{clccc}
\hline $\begin{array}{l}\text { Jumlah } \\
\text { Variabel }\end{array}$ & $\begin{array}{l}\text { Probabilitas Validasi } \\
\text { (Cronbach's Alpha) }\end{array}$ & R Tabel & $\begin{array}{l}\text { Reliabel } \\
\text { Jika CA>R tabel }\end{array}$ & kesimpulan \\
\hline 6 & 0,572 & 0,159 & $0,572>0,159$ & Reliabel \\
\hline
\end{tabular}

b. Uji Reliabilitas Tingkat Kepuasan

Tabel 6. Hasil Uji Reliabilitas Tingkat Kepuasan

\begin{tabular}{clccc}
\hline Jumlah Variabel & $\begin{array}{l}\text { Probabilitas Validasi } \\
\text { (Cronbach's Alpha) }\end{array}$ & R Tabel & $\begin{array}{l}\text { Reliabel } \\
\text { Jika CA>R tabel }\end{array}$ & kesimpulan \\
\hline 6 & 0,822 & 0,159 & $0,822>0,159$ & Reliabel \\
\hline
\end{tabular}

Dari tabel 5 dan 6 di atas, diketahui bahwa nilai koefisien reliabilitas (Cronbach Alpha) adalah 0,572 dan 0,822. Dinyatakan reliabel jika nilai cronbach alpha $>$ nilai $\mathrm{r}$ taabel pada $\mathrm{N}=134, \mathrm{DF}=\mathrm{N}-2=134-2=132$ dengan $\alpha=5 \%$. Maka nilai e tabe $=0,159 . \mathrm{N}$ adalah jumlah kuesioner yang disebar. Berdasarkan kriteria, nilai cronach alpha di atas sudah besar dari 0,159 , maka hasil data kuesioner memiliki tingkat reliabilitas yang baik atau dapat dipercaya.

\section{2) Tahap Kreatifitas}

Pada tahap kreatifitas ini dilakukan pengembangan ide dari rancangan produk yang memiliki nilai sesuai harapan responden (dalam hal ini mewakili teknisi) yang sesuai dengan hasil pada tahap informasi maka diperoleh ide-ide yang menjadi faktor penting pilihan konsumen yang berdasarkan variabel dari penyebaran kuisioner. Adapun ide perancangan produk yang diperoleh dari hasil wawancara sebagai berikut:

Tabel 7. Ide Rancangan Produk

\begin{tabular}{lllll}
\hline \multirow{2}{*}{ Variabel } & \multicolumn{3}{c}{ Ide } \\
\cline { 2 - 5 } & \multicolumn{2}{c}{ Alternatif 1 } & Alternatif 2 & \multicolumn{1}{c}{ Alternatif 3 } \\
\hline Mudah digunakan & $\begin{array}{l}\text { Item kerja bongkar pasang } \\
\text { pada semua bagian kompor }\end{array}$ & $\begin{array}{l}\text { Sistem } \\
\text { engsel pada kaki kompor }\end{array}$ & $\begin{array}{l}\text { kerja menggunakan } \\
\text { Sistem }\end{array}$ \\
& & & $\begin{array}{l}\text { menggunakan cope join } \\
\text { (dipen) pada kaki kompor } \\
\text { (poisi kaki kompor bisa di } \\
\text { bongkar pasang) }\end{array}$ \\
\hline $\begin{array}{l}\text { Desain } \\
\text { menarik }\end{array}$ & yang & $\begin{array}{l}\text { Memiliki desain yang } \\
\text { ramping, kuat dan elegan }\end{array}$ & $\begin{array}{l}\text { Memiliki bentuk seperti persegi } \\
\text { dan bulat pda bagian atasnya }\end{array}$ & $\begin{array}{l}\text { Memiliki desain tambahan } \\
\text { pada bagian samping } \\
\text { kompor }\end{array}$ \\
\hline
\end{tabular}




\begin{tabular}{|c|c|c|c|}
\hline $\begin{array}{l}\text { Daya tahan yang } \\
\text { kuat }\end{array}$ & $\begin{array}{l}\text { Material yang digunakan } \\
\text { adalah besi siku, plat besi }\end{array}$ & $\begin{array}{l}\text { Material yang digunakan adalah } \\
\text { besi hollow (stalbus), plat besi }\end{array}$ & $\begin{array}{l}\text { Material yang digunakan } \\
\text { adalah alumunium, plat } \\
\text { besi }\end{array}$ \\
\hline Multifungsi & Fungsi utama & $\begin{array}{l}\text { Memiliki fungsi lain dalam } \\
\text { penggunaan }\end{array}$ & - \\
\hline $\begin{array}{l}\text { Aman dan nyaman } \\
\text { saat digunakan }\end{array}$ & $\begin{array}{l}\text { Menggunakan } r \text { besi } \\
\text { tambahan pada engsel } \\
\text { sebagai penguat pada kaki } \\
\text { kompor }\end{array}$ & $\begin{array}{l}\text { Menggunakan cope join (dipen) } \\
\text { pada kaki kompor seingga } \\
\text { kompor bisa berdiri kokoh }\end{array}$ & - \\
\hline $\begin{array}{l}\text { Harga } \\
\text { ekonomis }\end{array}$ & $\begin{array}{l}\text { Harga berkisar } 50 \% \text { dari } \\
\text { harga produksi }\end{array}$ & $\begin{array}{l}\text { Harga disesuaikan dengan } \\
\text { permintaan jumlah yang dipesan } \\
\text { dan diberikan diskon }\end{array}$ & $\begin{array}{l}\text { Harga relatif murah dan } \\
\text { disesuaikan dengan harga } \\
\text { pasar saat ini }\end{array}$ \\
\hline
\end{tabular}

3) Tahap Analisa

a. Analisa Ide Kreatif

Pada tahap ini akan mengevaaluasi aalternatif berdasarkan kuesioner yang disebar pada tahap kreatifitas kepada 134 pelaku usaha. Adapun rekapitulasi data kuesioner berdasarkan pilihan kuesioner sebagai berikut:

Tabel 8. Rekapitulasi Data Kuesioner Berdasarkan Pilihan Responden

\begin{tabular}{lcccc}
\hline \multirow{2}{*}{ Variabel } & \multicolumn{3}{c}{ Jawaban Responden } & \multirow{2}{*}{ Jumlah } \\
\cline { 2 - 4 } & $\mathbf{1}$ & $\mathbf{2}$ & $\mathbf{3}$ & \\
\hline Mudah digunakan & 10 & 36 & 88 & 134 \\
Desain yang menarik & 77 & 15 & 42 & 134 \\
Daya tahan yang kuat & 14 & 87 & 33 & 134 \\
Multifungsi & 18 & 116 & - & 134 \\
Aman dan nyaman saat digunakan & 29 & 105 & - & 134 \\
Harga yang ekonomis & 20 & 28 & 86 & 134 \\
\hline
\end{tabular}

Dari tabel di atas dijelaskan bahwa pada variabel 1, pilihan responden dominan kepada alternatif ketiga dengan jumlah 88, untuk variabel 2 dominan pada alternatif pertama dengan jumlah 77, untuk variabel 3 dominan kepada alternatif kedua dengan jumlah 87, untuk variabel 4 dominan pada alternatif kedua dengan jumlah 116, untuk variabel 5 dominan pada alternatif kedua dengan jumlah 105 sedangkan untuk variabel 6 dominan pada alternatif ketiga dengan jumlah 86 .

\section{b. Analisa Biaya Bahan Baku}

Tabel 9. Karakteristik dan harga Biaya Bahan Baku

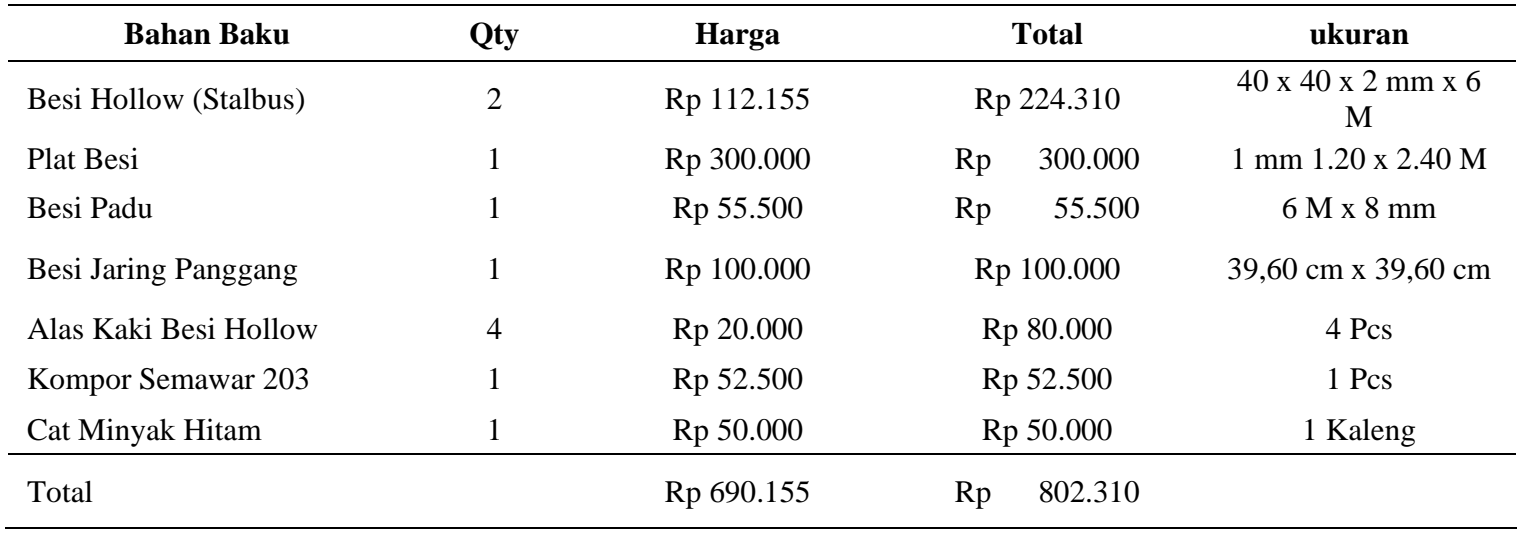

\section{c. Analisa Data Antropometri}

Pengolahan data antropometri ini menggunakan data subjek dari 135 orang pelaku usaha pecel lele yang berada di Pekanbaru dengan jumlah responden pria sebanyak 83 orang dan wanita 
sebanyak 51 orang. Hasil dari perhitungan ini akan digunakan untuk mencari dimensi dari alat yang akan dibuat. Adapun data yang digunakan dalam perhitungan sebagai berikut:

Tabel 10. Data yang Digunakan untuk Perhitungan

\begin{tabular}{|c|c|c|c|c|c|c|c|c|}
\hline No & Dimensi Tubuh & Simbol & Penggunaan Ukuran & \multicolumn{4}{|c|}{ Persentil (cm) } \\
\cline { 6 - 9 } & & P5 & P10 & P50 & P90 & P95 \\
\hline 1 & $\begin{array}{l}\text { Rentangan siku } \\
\text { dalam posisi berdiri }\end{array}$ & D33 & $\begin{array}{l}\text { Digunakan untuk ukuran } \\
\text { panjang kompor secara penuh }\end{array}$ & 65,9 & 66,1 & 66,6 & 67,2 & 67,4 \\
\hline 2 & $\begin{array}{l}\text { Panjang lengan atas } \\
\text { dalam posisi duduk }\end{array}$ & D23 & $\begin{array}{l}\text { Digunakan untuk ukuran } \\
\text { lebar kompor secara penuh }\end{array}$ & 38,6 & 38,7 & 39,3 & 39,8 & 40,0 \\
\hline 3 & $\begin{array}{l}\text { Tinggi tulang ruas } \\
\text { pda posisi berdiri }\end{array}$ & D6 & $\begin{array}{l}\text { Digunakan untuk ukuran } \\
\text { tinggi kompor secara penuh }\end{array}$ & 73,2 & 73,4 & 74,2 & 74,9 & 75,2 \\
\hline
\end{tabular}

Tabel 11. Data Persentil yang Terpilih untuk Perancangan Kompor Ergonomis

\begin{tabular}{|c|l|c|c|c|}
\hline No & Data Geometris & Persentil & Hasil Dari & Dimensi (cm) \\
\hline 1 & Panjang & P50 & $2 \times$ D33 & 133,2 \\
\hline 2 & Lebar & P95 & D23 & 40 \\
\hline 3 & Tinggi & P95 & D6 & 75,2 \\
\hline
\end{tabular}

Pengukuran antropometri.

A. Rentangan Siku dalam Posisi Berdiri (D33)

1. Mean / rata-rata $(\overline{\mathrm{X}})$

$\sum \overline{\mathrm{X}} \mathbf{1}$ Total rata-rata sub group adalah $=8997 \mathrm{~cm}$

$\overline{\mathrm{X}} \quad=\frac{\sum \overline{\mathrm{X}} \mathrm{l}}{k}=\frac{8997}{135}=66,6 \mathrm{~cm}$

Dimana:

$$
\begin{aligned}
& \overline{\mathrm{X}}=\text { mean/rata-rata } \\
& \mathrm{k}=\text { banyak data } \\
& \sum \overline{\mathrm{X}} \mathrm{l}=\text { nilai data ke- } \mathrm{i}
\end{aligned}
$$

2. Standar Deviasi / Simpangan Baku $(\sigma)$

$$
\begin{gathered}
\sigma=\frac{\sqrt{\Sigma(x i-\bar{X})^{2}}}{\mathrm{~N}-1} \\
\sigma=\frac{\sqrt{\Sigma(64-66,6)^{2}+(67-66,6)^{2}+(65-66,6)^{2} \ldots \ldots \ldots(69-66,6)^{2}}}{135-1} \\
\sigma=\frac{391,6}{134}=1,7 \mathrm{~cm}
\end{gathered}
$$

Dimana:

$$
\begin{aligned}
& \sigma=\text { standar deviasi (simpangan baku) } \\
& \mathrm{xi}=\text { nilai data ke-i } \\
& \overline{\mathrm{X}}=\text { mean/rata-rata } \\
& \mathrm{N}=\text { banyaknya data }
\end{aligned}
$$

3. Standar Deviasi Rata-rata

$\sigma \mathrm{x}=\frac{\sigma}{\sqrt{\mathrm{N}}}=\frac{1,7}{\sqrt{15}}=0,4 \mathrm{~cm}$

Dimana:

$$
\begin{array}{ll}
\sigma \mathrm{x} & =\text { standar deviasi rata-rata } \\
\frac{\sigma}{\sqrt{\mathrm{N}}} & =\text { standar deviasi } \\
& =\text { Akar dari jumlah data }
\end{array}
$$

4. Uji Keseragaman Data

$$
\begin{aligned}
& \mathrm{BKA}=\overline{\mathrm{X}}+2 . \sigma \mathrm{x}=66,6+2 \times 0,4=67,5 \mathrm{~cm} \\
& \mathrm{BKB}=\overline{\mathrm{X}}-2 . \sigma \mathrm{x}=66,6-2 \times 0,4=65,8 \mathrm{~cm}
\end{aligned}
$$


Dimana:

$$
\begin{array}{ll}
\sigma \mathrm{x} & =\text { standar deviasi rata-rata } \\
\overline{\mathrm{X}} & =\text { mean/rata-rata } \\
\mathrm{BKA} & =\text { Batas Kontrol Atas } \\
\mathrm{BKB} & =\text { Batas Kontrol Bawah }
\end{array}
$$

5. Uji Persentil $(5 \%, 10 \%, 50 \%, 90 \%, 95 \%)$

Persentil $5=\bar{X}-1,645 \times \sigma x=66,6-1,645 \times 0,4=65,9 \mathrm{~cm}$

Persentil $10=\bar{X}-1,28 \times \sigma x=66,6-1,28 \times 0,4=66,1 \mathrm{~cm}$

Persentil $50=\overline{\mathrm{X}}=66,6=66,6 \mathrm{~cm}$

Persentil $90=\bar{X}-1,28 \times \sigma x=66,6+1,28 \times 0,4=67,2 \mathrm{~cm}$

Persentil $95=\bar{X}+1,645 \times \sigma x=66,1+1,645 \times 0,4=67,4 \mathrm{~cm}$

d. Analisa Bahan Baku

\begin{tabular}{|c|c|c|c|c|c|c|}
\hline Material & Ukuran & Harga (Rp) & $\begin{array}{l}\text { Ukuran } \\
\text { Terpakai } \\
\quad \text { (cm) }\end{array}$ & $\begin{array}{c}\text { Scraps } \\
(\mathbf{c m})\end{array}$ & $\begin{array}{l}\text { Per } \\
\text { Unit }\end{array}$ & $\begin{array}{c}\text { Harga } \\
\text { Bahan } \\
\text { Baku Per } \\
\text { Unit (Rp) }\end{array}$ \\
\hline $\begin{array}{l}\text { Besi Hollow } \\
\text { (Stalbus) }\end{array}$ & $\begin{array}{c}40 \times 40 \times 2 \mathrm{~mm} \times \\
12 \mathrm{M}\end{array}$ & 224.310 & 953,6 & 246,4 & 2 & 178.252 \\
\hline Plat Besi & $\begin{array}{c}1 \mathrm{~mm} 1.20 \times 2.40 \\
\mathrm{M}\end{array}$ & 300.000 & $98,2 \times 106,6$ & $\begin{array}{c}21,8 \mathrm{x} \\
133,4 \\
\end{array}$ & 1 & 113.160 \\
\hline Besi Padu & 6 meter $\times 8 \mathrm{~mm}$ & 55.500 & 124,16 & 475,84 & 1 & 11.522 \\
\hline $\begin{array}{l}\text { Besi Jaring } \\
\text { Panggang }\end{array}$ & $\begin{array}{c}39,60 \mathrm{~cm} \mathrm{x} 39,60 \\
\mathrm{~cm}\end{array}$ & 100.000 & $\begin{array}{l}39,60 \mathrm{~cm} \mathrm{x} \\
39,60 \mathrm{~cm}\end{array}$ & 0 & 1 & 100.000 \\
\hline $\begin{array}{l}\text { Alas kaki besi } \\
\text { hollow }\end{array}$ & $4 \mathrm{Pcs}$ & 20.000 & $4 \mathrm{Pcs}$ & 0 & 4 & 20.000 \\
\hline $\begin{array}{l}\text { Kompor } \\
\text { semawar } 203\end{array}$ & $1 \mathrm{Pcs}$ & 52.500 & $1 \mathrm{Pcs}$ & 0 & 1 & 52.500 \\
\hline \multirow[t]{2}{*}{$\begin{array}{l}\text { Cat minyak } \\
\text { hitam }\end{array}$} & 1 Kaleng & 50.000 & 1 Kaleng & 0 & 1 & 50.000 \\
\hline & & Total & & & & 525.434 \\
\hline
\end{tabular}

Setelah dilakukan pengumpulan dan pengolahan data antropometri, maka dilakukan estimasi bahan baku per unit dan ukuran bahan baku yang digunakan.

Tabel 13. Biaya Bahan Baku Per Unit

4) Tahap Pengembangan

Dalam tahap ini semua ide yang sudah dievaluasi, akan direalisasikan dalam bentuk gambar 2 dimensi yang menjelaskan hasil dari ide alternatif yang terpilih sesuai keinginan pengguna berdasarkan kuesioner yang disebar, berikut ini adalah penjelasannya:

a. Kemudahan Penggunaan Alat

Ide dari variabel ini menjelaskan bagaimana cara kerja sistem alat ini dengan menggunakan baut/sekrup pada kaki kompor sehingga kaki-kaki kompor dapat di bongkar pasang yang memudahkan para pelaku usaha pecel lele warung tenda dalam perpindahpindah tempat karena sifat dari kompor ini yaitu portable (dapat dipindah-pindahkan). Dalam merakit kompor ini sangat mudah karena tinggal memasangkan kaki kompornya dan dibuka penutup atasnya yang berfungsi sebagai tempat bahan-bahan masak atau lainnya dalam usaha pecel lele. 


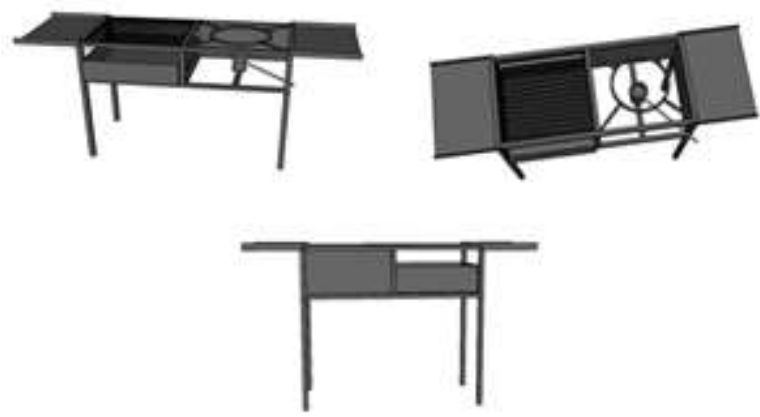

Gambar 2. Desain Kompor 3D

b. Memiliki Desain yang Menarik

Unit ini memiliki desain yang menarik dalam hal bentuk fisiknya, ramping dalam segi ukuran dan pemakaian karena dapat dijinjing serta dapat dibongkar pasang, kuat dalam dudukan pada kaki-kai kompor yang memakai sistem kerja baut/sekrup dan elegan dalam penampilan karena bentuknya yang unik dan berbeda.

c. Memiliki Daya Tahan yang Kuat

Material yang digunakan dalam penelitian ini adalah material yang tahan, kuat saat digunakan dan anti karat. Seluruh sambungan material yang digunakan dirancang menjadi sebuah unit yang tangguh yang tiap sambungannya di las dengan rapi dan bersih.

d. Multifungsi

Kompor ini dirancang untuk memudahkan penggunanya dalam melakukan aktivitasnya sehingga kompor ini memiliki lebih dari satu fungsi yaitu sebagai kompor memasak dan sebagai tempat panggangan yang mana dua kegiatan tersebut bisa dilakukan sekaligus yang bisa menghemat waktu dan bekerja secara efektif dan efisien.

e. Aman dan Nyaman Saat Digunakan

Keamanan dalam penggunaan alat adalah merupakan suatu hal yang sangat penting dalam perancangan produk karena hal ini mengandung nilai lebih dari suatu produk yang akan dibuat. Dapat dipahami bahwa kenyamanan, keindahan dipengaruhi oleh bentuk, tekstur, warna produk dan material yang digunakan. Pada alat ini tidak hanya mempertimbangkan fungsi secara teknis saja melainkan juga dapat mempertimbangkan faktor kenyamanan dan keamanan dalam memakai. Kompor ini telah dirancang sesuai antropometri yang diharapkan bisa pelaku usaha pecel lele dapat bekerja dengan efektif, nyaman, aman, sehat dan efisien yang bisa memperbaiki sistem kerja yang buruk kearah yang lebih baik dalam perancangan kompor ini.

f. Harga yang Ekonomis

Dalam masalah harga untuk alat ini sangat murah dan terjangkau bagi penggunanya. Karena dilihat dari segi fungsi dan kegunaannya sangat membantu bagi pelaku usaha pecel lele untuk menunjang kegiatan usahanya. Sehingga kebutuhan kompor yang ergonomis terpenuhi dan bisa dikerjakan sekaligus secara berbarengan antara penggorengan dan pemanggangan sehingga bisa lebih cepat dan efisien. Seperti yang telah di sebutkan diawal untuk harga total bahan baku yang dikeluarkan dalam rancangan alat ini sebesar Rp.802.310,-dan untuk harga modal unit adalah Rp 525.434,--

\section{5) Tahap Rekomendasi}

Berdasarkan hasil tahapan sebelumnya dari tahap informasi, tahap kreatifitas, tahap analisa dan tahap pengembangan maka telah dapat dibuat suatu kesimpulan untuk menentukan rekomendasi kompor ergonomis dengan konversi bahan bakar plastik dan minyak menjadi bahan bakar gas. Berikut adalah rekomendasi kompor yang terpilih yang sesuai dengan kebutuhan pengguna. 


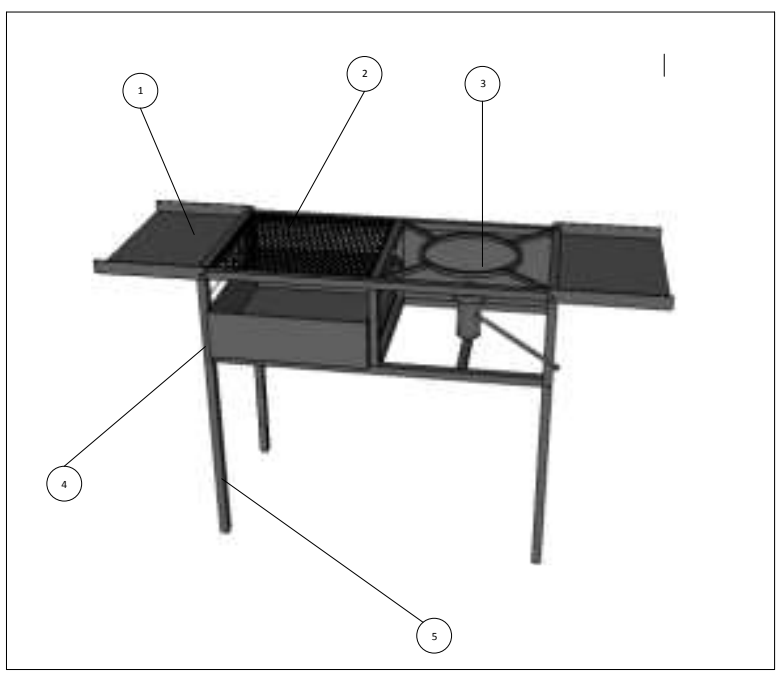

Gambar 3. Desain Kompor 3D

Tabel 14. Nama dan Fungsi Komponen Kompor

\begin{tabular}{|c|c|c|}
\hline No & Nama Komponen & Fungsi Komponen \\
\hline 1 & Penutup Atas/Meja & $\begin{array}{l}\text { Sebagai tempat meletakkan bahan-bahan } \\
\text { masakan dan lainnya, Sebagai penutup kompor } \\
\text { apabila dilipat. }\end{array}$ \\
\hline 2 & Tempat Panggangan & Sebagai tempat memanggang masakan \\
\hline 3 & Kompor & Sebagai tempat memasak \\
\hline 4 & Cope Joint (dipen) & Untuk penguat kaki-kaki kompor \\
\hline 5 & Kaki Kompor & untuk dudukan pada rangka kompor \\
\hline
\end{tabular}

Untuk nama kompor ini yang direkomendasikan adalah "Mix Gas Stove".

\section{Rancangan Kompor Tidak Ergonomis}

Berikut salah satu contoh desain kompor tidak ergonomis yang banyak digunakan oleh pelaku usaha pece lele di Pekanbaru:

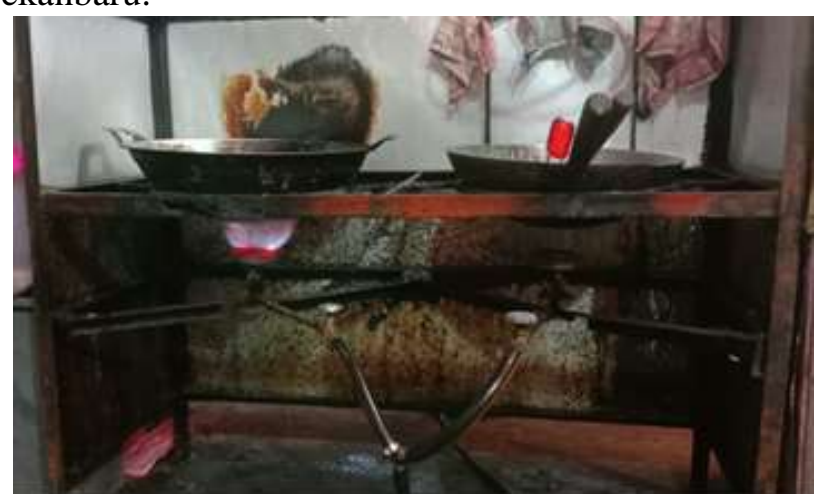

Gambar 4. Kondisi Kompor Sebelum Perancangan

Dari gambar di atas terlihat bahwa kondisi kompor yang tidak minimalis memerlukan ruang yang luas untuk meletakkan kompor tersebut. Posisi dan bentuk dari kompor yang tidak ergonomis bisa lebih tinggi atau lebih rendah dari kondisi fisik pekerja, dapat menimbulkan ketidaknyamanan dalam bekerja. Untuk itu, pelaku usaha pecel lele harus lebih memperhitungkan teknologi memasak yang digunakan, dan juga memahami karaktersitik fisiologi dan psikologi para pekerja. 


\section{Perancangan Kompor Ergonomis}

Pada tahap ini ditunjukkan hasil dari rancangan kompor ergonomis dalam bentuk dan ukuran $\mathrm{cm}$ yang diperoleh dari hasil pengukuran antropometri sebagai berikut:

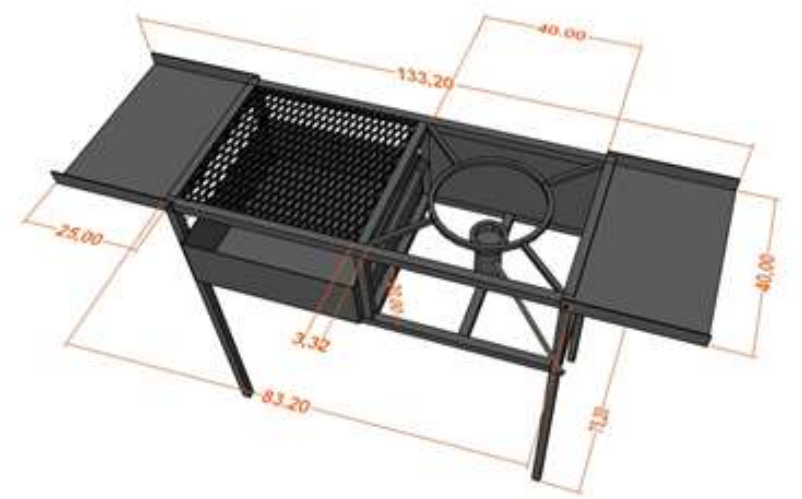

Gambar 5. Desain dan Ukuran Kompor Ergonomis 3D (dalam ukuran cm)

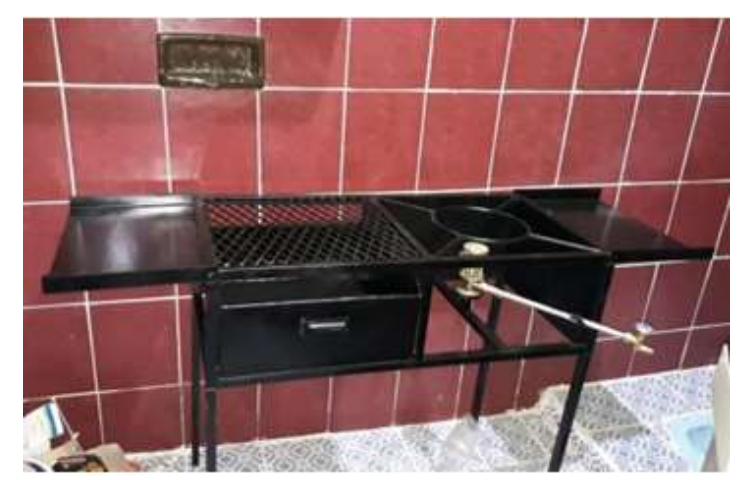

Gambar 6. Kondisi Kompor Setelah Perancangan

\section{Rancangan dan Pembuatan Sistem Pendukung Terintegrasi pada Kompor}

Dalam rancangan dan pembuatan sistem pendukung terintegrasi ini terdapat dua alat pendukung pada pembuatan kompor ini yaitu sistem pengolahan sampah plastik menjadi bahan bakar alternatif dan alat konversi energi dari cair menjadi gas. Perancangan ini dilakukan untuk mengintegrasikan semua sistem menjadi satu kesatuan lengkap tidak hanya merancang kompor tetapi disini peneliti juga merancang bahan bakar yang digunakan dalam pengopersian kompor tersebut.

\section{Rancangan dan Pembuatan Alat Pengolahan Sampah Plastik Menjadi Bahan Bakar Alternatif}

Alat pengolahan sampah plastik ini berfungsi sebagai salah satu bahan bakar yang akan digunakan dalam proses pengapian pada kompor. Tujuannya untuk mengurangi sampah plastik secara bertahap sehingga diharapkan dalam pemakaian sampah plastik ini dapat menghemat sumber daya alam seperti minyak bumi dan gas.

Pada proses pengolahan ini peneliti telah melakukan studi literatur berupa jurnal tentang pengolahan sampah plastik menjadi bahan bakar dan juga melalui wawancara kepada para pakar baik dari akademisi maupun lapangan. Dalam perancangan ini ada beberapa variabel yang dibutuhkan dalam merancang alat ini yaitu:

1. Metode yang dilakukan merupakan metode pirolisis yaitu dekomposisi termokimia bahan organik melalui proses pemanasan tanpa atau sedikit oksigen atau pereaksi kimia lainnya, kemudian material mentah akan mengalami pemecahan struktur kimia menjadi fase gas.

2. Perancangan bahan bakar untuk proses pemanasan plastik memakai kompor oli bekas. 
3. Sistem pendinginan uap plastik menjadi cair dilakukan dengan cara destilasi spiral dalam kondisi air bersuhu normal akan bertemu dengan uap bersuhu tinggi yang akan mentransfer panasnya (Heat Exchanger) kepada air sehingga uap tadi lebih cepat berubah ke fase cair. Sistem pendinginan yang kita gunakan dalam posisi vertikal.

4. Dalam proses akhir peneliti hanya menampung cairan yang berupa minyak yang setara dengan bensin (premium) dan yang lain diabaikan. Tujuannya ntuk menguji keefektifan pertukaran panas (Heat Exchanger) yang terjadi pada sistem pendingin tersebut.

5. Hasil akhir berupa bahan bakar plastik tersebut akan kita konversikan menjadi gas dengan campuran bahan bakar minyak (premium ataupun pertalite).

Dari beberapa variabel tersebut maka terbentuklah suatu rancangan alat pengolahan sampah menjadi bahan bakar alternatif yang di rancang oleh peneliti sendiri. Adapun bentuk rancangan alat pengolahan sampah menjadi bahan bakar alternatif sebagai berikut:

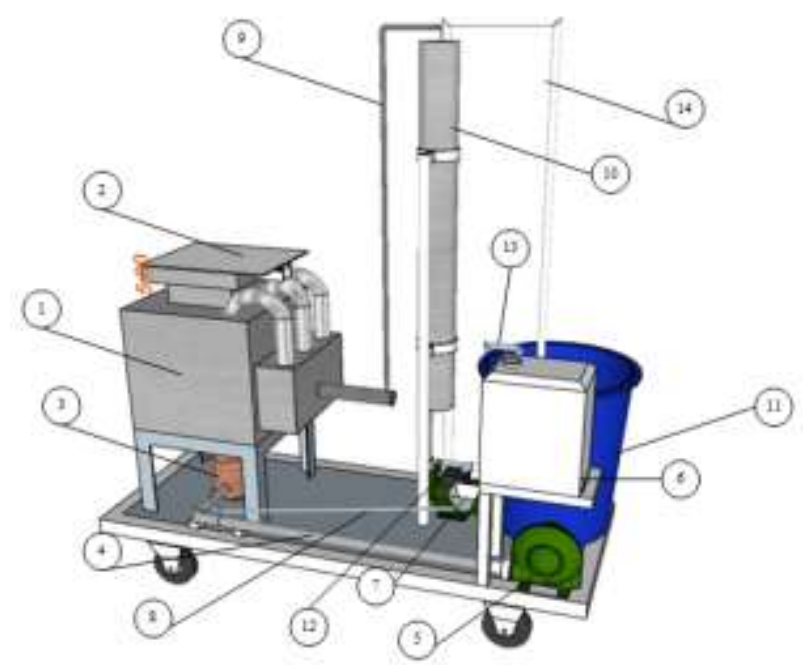

Gambar 7. Desain Alat Pengolahan Sampah Plastik

Tabel 15. Nama dan Fungsi Komponen Alat Pengolah Sampah

\begin{tabular}{|c|c|c|}
\hline No & Nama Komponen & Fungsi Komponen \\
\hline 1 & Reaktor/Tempat Pembakaran & Sebagai wadah pembakaran sampah plastik \\
\hline 2 & Mainhole & Tempat penutup utama reaktor/tempat pembakaran \\
\hline 3 & Tungku Api & $\begin{array}{l}\text { Tempat berlangsungnya pengapian untuk proses pembakaran pada } \\
\text { reaktor/tempat pembakaran }\end{array}$ \\
\hline 4 & LineBlower (Exhaust Fan) & Sebagai lewatnya aliran udara menuju tungku api \\
\hline 5 & Blower (Exhaust Fan) & $\begin{array}{l}\text { Untuk menghembuskan udara sehingga oli bekas bisa masuk menuju } \\
\text { tungku api dengan cepat dan pembakarannya sempurna }\end{array}$ \\
\hline 6 & Drum Oli Bekas & Tempat penampungan oli bekas \\
\hline 7 & Tempat Oli Bekas & Untuk menampung oli bekas menuju line oli bekas \\
\hline 8 & Line Oli Bekas & Sebagai lewatnya aliran oli menuju tungku api \\
\hline 9 & Line Uap & Tempat lewatnya aliran uap hasil pembakaran sampah plastic \\
\hline 10 & Tabung Pendingin & $\begin{array}{l}\text { Tempat terjadi proses Heat Exchanger pada uap menjadi fase cair } \\
\text { dengan bantuan pendingin berupa air dalam kondisi normal }\end{array}$ \\
\hline 11 & Ember Air & Sebagai tempat penampungan air \\
\hline 12 & Pompa Air & Untuk mempompakan air ke dalam tabung pendingin secara sirkulasi \\
\hline 13 & Line Air Masuk & Tempat masuknya air dari ember air menuju tabung pendingin \\
\hline 14 & Line Air Keluar & Tempat keluarnya air tabung pendingin menuju ember air \\
\hline
\end{tabular}




\section{Rancangan dan Pembuatan Alat Konversi Energi dari Fase Cair Menjadi Fase Gas}

Pada rancangan alat ini berfungsi sebagai pengubah energi dari fase cair menjadi fase gas, yang mana dalam hal ini fase cairnya berupa campuran bahan bakar plastik dan bahan bakar minyak (premium ataupun pertalite) yang akan dirubah menjadi fase gas yang bertujuan sebagai bahan bakar pada kompor tersebut. Ini sebagai upaya untuk menghemat sumber daya alam yaitu minyak bumi dan gas, maka sebagai langkah awal peneliti mencampurkan kedua bahan bakar tersebut karena untuk bahan bakar plastik sendiri yang kita hasilkan belum mencapai hasil yang maksimal. Adapun skema alat konversi dari fase cair ke fase gas sebagai berikut:

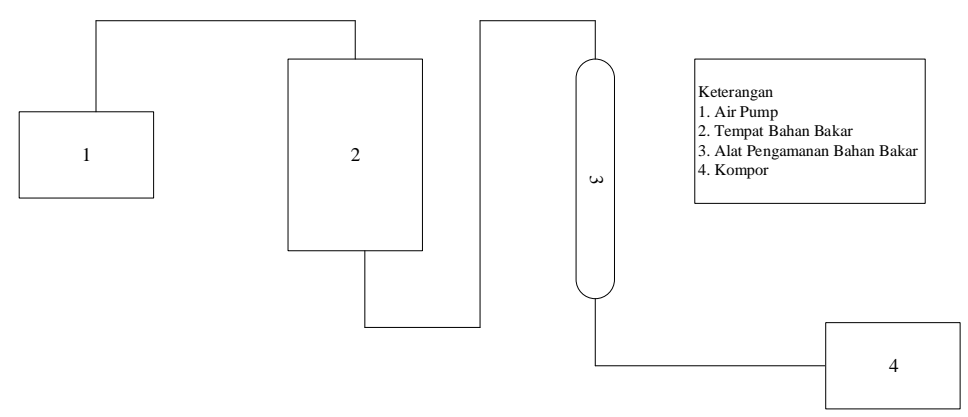

Gambar 8. Skema Alat Konversi dari Fase Cair ke Fase Gas

Prinsip kerjanya adalah air pump memberikan udara pada tempat bahan bakar disana akan terjadi gelembung-gelumbung udara yang akan merubah bahan bakar tersebut menjadi gas-gas karena memiliki nilai oktan. Setelah berubah menjadi gas, gas tersebut melewati alat pengamanan bahan bakar yang berfungsi apabila air pump dimatikan aliran balik gas tidak langsung menyentuh bahan bakar tetapi melewati alat pengamanan bahan bakar sehingga gas tersebut bisa teredam pada alat pengaman tersebut, alat pengamanan tersebut berisi sabut baja. Setelah gas tersebut melewati alat pengamanan bahan bakar kemudian menuju kompor dan bisa diatur besar kecil apinya pada kompor.

\section{Simpulan}

Hasil dari penelitian ini dapat disimpulkan bahwa spesifikasi alat yang dibutuhkan oleh pelaku usaha pecel lele dapat diketahui dari sejumlah aspek seperti mudah digunakan, memiliki desain yang menarik, memiliki daya tahan yang kuat, aman dan nyaman saat digunakan dan harga yang ekonomis. Rancangan kompor ergonomis dengan konversi bahan bakar plastik dan minyak menjadi bahan bakar gas yang sesuai dengan kebutuhan usaha pecel lele adalah peralatan yang mudah untuk digunakan, sistem kerja sangat praktis dan mudah dimengerti oleh pengguna, memiliki desain yang menarik, ramping, kuat dan elegan saat digunakan, mempunyai daya tahan yang kuat. Untuk material yang digunakan berbahan dasar Besi Hollow (Stalbus), Plat Besi, Besi Padu, Besi Jaring Panggang, Alas Kaki Besi Hollow, Kompor Semawar 203 dan Cat Minyak Hitam.

Selain memiliki fungsi utama sebagai kompor, alat ini juga memiliki fungsi lain sebagai tempat pemanggang yang mana tempat ini saat berguna bagi pelaku usaha pecel lele dalam proses pemanggangan usahanya yang tidak memerlukan banyak tempat serta praktis dalam penggunaanya, memiliki sistem kerja dengan menggunakan baut/sekrup sehingga untuk kaki-kaki kompor bisa lebih kuat, aman dan nyaman pada saat digunakan, harganya relatif murah dan disesuaikan dengan harga pasar saat ini, dan rancangan kompor ergonomis dengan dua alat sistem pendukung yaitu alat pengolahan sampah plastik menjadi bahan bakar alternatif dan alat konversi energi dari fase cair menuju fase gas. Kedua rancangan ini sangat mendukung kerja dari kompor, dalam hal ini kita menggunakan energi campuran yaitu bahan bakar plastik dan minyak sebagai 
bahan bakar utama pada kompor tersebut sehingga bisa mengurangi dampak limbah sampah plastik serta menghemat sumber daya alam berupa minyak bumi dan gas.

Adapun saran yang dapat diberikan dari penelitian ini adalah rancangan alat dalam penelitian ini adalah rancangan alat dalam penelitian ini dapat dikembangkan lebih lanjut dengan penambahan alat multifungsi lainnya. Seperti penambahan tempat penyaringan minyak pada bagian atas kompor. Untuk rancangan alat pengolah sampah plastik harus terus dikembangkan sehingga menjadi bahan bakar yang bisa memiliki nilai oktan yang setara dengan premium atau lebih diatasnya. Seperti dengan penambahan bahan kimia untuk mempercepat proses pembakaran sehingga pembakarannya menjadi lebih sempurna, perlunya alat tambahan pada hasil akhir dengan menambah tabung pendingin kecil sehingga semua uap bisa dihasilkan ke fase cairan dengan maksimal. Bagi peneliti berikutnya, diharapkan dapat melanjutkan penelitian ini dengan menambah metode, karakteristik dan aspek kelayakan dalam rancangan ini.

\section{DAFTAR PUSTAKA}

Adhani,Laksmira Kusumo, (2017) Pengembangan rancangan alat tenong yang ergonomis menggunakan metode value engineering \& kansei engineering di perusahaan makanan x Yogyakarta, Skripsi UGM Yogyakarta

Arikunto, S. (2010). Prosedur Penelitian suatu Pendekatan Praktek. Jakarta: Rineka Cipta.

Chandra, C. S. (2014). Maximizing Consruction Project and Investment Budget Efficiency with Value Engineering. Jakarta: PT. Elex Media Komputindo.

Haryanto, L. T. (2012). Perancangan Ulang Alat Bantu Jalan (Walker) untuk Pasien Pasca Stroke Menggunakan Metode Value Engineering.

Kholisyah, Z. (2019). Analisis Beban Emisi Karbon Monoksida (CO) dan Methana (CH4) dari Kegiatan Pembakaran Sampah RUmah Tangga Secara Terbuka (Studi kasus Kec. Sarirejo, Kab. Lamongan.

P.Bhattacharya, P. S. (2009). Wood/Plastic co-Pyrolysis in an Auger Reactor: Chemical and Physical Analysis of The Product. Fuel. 1251-1260.

Prasetyo, H. (2010). Mesin Pengolah Limbah Sampah Plastik Menjadi Bahan Bakar Alternatif.

Sokhibi, A. (2017). Perancangan Kursi Ergonomis untuk Memperbaiki Posisi Kerja pada Proses Packaging Jenang Kudus. Jurnal Rekayasa Sistem Industri, 61-72.

Subiantoro, I. (2015). Rancang Bangun Kompor Batubara untuk Kebutuhan Industri Rumah Tangga. JRM, Vol. 02, No.03, 64-67. 
[ Halaman kosong ] 